\title{
ANNOUNCEMENTS
}

The 156th meeting of the

\section{PATHOLOGICAL SOCIETY OF GREAT BRITAIN AND IRELAND} will be held at ST BARTHOLOMEW'S HOSPITAL, LONDON

on January 6th, 7th and 8th, 1988

Microbiology programme

Wednesday January 6th a.m. Symposium-New anaerobic pathogens. (A joint meeting with the Anaerobe Discussion Group).

p.m. Free papers and posters.

Thursday January 7 th a.m. Symposium-Novel approaches to epidemiological typing.

12.00 noon 10 th C. L. Oakley Lecture.

p.m. Free papers and posters.

Further information may be obtained from the Meetings Secretary:

Professor E. Mary Cooke, Central Public Health Laboratory,

Division of Hospital Infection, 61 Colindale Avenue, London NW9 5HT.

Tel: 01-200 4400 Ext 4249.

\section{PATHOLOGICAL SOCIETY FELLOWSHIPS}

The Pathological Society of Great Britain and Ireland are sponsoring a small number of Fellowships to enable members of the medical and scientific professions working in UK or Ireland in experimental and/or pathologically or microbiologically-related research to visit other institutions for periods up to 12 months to learn new investigative techniques. Preference will be given to those requiring additional funds to augment existing salary. Closing date for applications October 30th, 1987. Further details and application forms from Professor R. B. Goudie, Department of Pathology, Royal Infirmary, Glasgow G4 0SF.

\section{THE WORLD ASSOCIATION OF VETERINARY MICROBIOLOGISTS, IMMUNOLOGISTS AND SPECIALISTS OF INFECTIOUS DISEASES}

First World Congress

LYON, France

July 25th-29th, 1988

The programme includes new developments in animal bacteriology, virology, immunology and infectious diseases of domestic animals.

Also new diagnostic methods, prevention and therapy of these diseases are included. A special session will be reserved for the zoonoses.

The Congress will be of interest not only to specialists working in diagnostic, protection and quality control laboratories but also to veterinarians dealing with infectious diseases of different animal species as well as colleagues specialised in Public Health.

Further information from:

Professor Y. Richard,

École Nationale Vétérinaire de Lyon, route de Sain Bel, Marcy-l'Etoile,

69260 Charbonnières-les-Bains, Lyon, France. 